\title{
MENINGKATKAN HASIL BELAJAR SISWA DENGAN MENGGUNAKAN METODE PETA KONSEP PADA MATA PELAJARAN ILMU PENGETAHUAN SOSIAL KELAS III SEKOLAH DASAR NEGERI 65/II SUNGAI BANGSAT BUNGO
}

\author{
Fitria Carli Wiseza \\ Institut Agama Islam Yasni Bungo \\ Email: fitriawiseza@gmail.com
}

\begin{abstract}
This research was conducted aiming to improve student learning outcomes through the concept map method in learning activities. The type of research in this thesis is Classroom Action Research (CAR). The research subjects were third grade students of SDN 65/II Sungai Bangsat Bungo, totaling 24 students, 12 male students and 12 female students. This research includes 2 cycles. Each cycle consists of 4 stages in its implementation, namely planning, implementing actions and observations, and reflection. For data collection techniques in the form of observation sheets, interviews, and learning outcomes tests. And the data analysis technique in the form of an assessment scale includes 4 categories of learning achievement achievement. The results of the study obtained an increase in student learning outcomes in Cycle I by $58 \%$ which was in the fairly good category and increased again in Cycle II to $88 \%$ in the very good category of the total number of third grade students at SDN 65/II Sungai Bungo bastard. Based on the results of the study, it was concluded that the concept map method carried out during learning activities had been proven to improve the learning outcomes of third grade students at SDN 65/II Sungai Bangsat Bungo.
\end{abstract}

Keywords: Student Learning Outcomes, Social Science Learning Concept Map Method

\begin{abstract}
Abstrak
Penelitian ini dilakukan bertujuan untuk meningkatkan hasil belajar siswa melalui metode peta konsep dalam kegiatan pembelajaran. Jenis penelitian dalam skripsi ini adalah Penelitian Tindakan Kelas (PTK). Subjek penelitian yaitu siswa kelas III SDN 65/II Sungai Bangsat Bungo, yang berjumlah 24 siswa, 12 siswa laki-laki dan 12 siswa perempuan. Dalam penelitian ini meliputi 2 siklus. Setiap siklus terdiri dari 4 tahap dalam pelaksanaannya yaitu perencanaan, pelaksanaan tindakan dan observasi, serta refleksi. Untuk teknik pengumpulan datanya berupa lembar observasi, wawancara,
\end{abstract}

Nur El-Islam, Volume 8, Nomor 2, Oktober 2021 
dan tes hasil belajar. Dan teknik analisis data berupa skala penilaian mencakup 4 kategori pencapaian hasil belajar. Hasil penelitian yang diperoleh mengalami peningkatan pada hasil belajar siswa di Siklus I sebesar 58\% yang berada pada kategori cukup baik dan mengalami peningkatan kembali pada Siklus II menjadi sebesar $88 \%$ berada pada kategori sangat baik dari jumlah keseluruhan siswa kelas III di SDN 65/II Sungai Bangsat Bungo. Berdasarkan hasil penelitian tersebut, maka disimpulkan bahwa melalui metode peta konsep yang dilakukan selama kegiatan pembelajaran telah terbukti dapat meningkatkan hasil belajar siswa kelas III SDN 65/II Sungai Bangsat Bungo.

Kata Kunci : Hasil Belajar Siswa, Metode Peta Konsep Pembelajaran IPS

\section{Pendahuluan}

Pendidikan adalah usaha sadar untuk mengembangkan akhlak, keterampilan, dan pengetahuan dalam mewujudkan suasana belajar dan proses pembelajaran agar peserta didik secara aktif mengembangkan potensi dirinya untuk memiliki kekuatan spiritual keagamaan, pengendalian diri, kepribadian, kecerdasan, akhlak mulia, serta keterampilan yang diperlukan dirinya, masyarakat, bangsa dan negara. ${ }^{1}$ Dalam Undang-undang No. 20 Tahun 2017 tentang Sistem Pendidikan Karakter adalah gerakan pendidikan di bawah tanggung jawab satuan pendidikan untuk memperkuat karakter peserta didik melalui harmonisasi oleh hati, olah rasa, olah piker, dan olah raga dengan pelibatan dan kerja sama antara satuan pendidikan, keluarga, dan masyarakat dalam tujuan pendidikan nasional dan pendidikan di sekolah dasar yaitu, untuk mewujudkan suasana belajar dan proses kegiatan pembelajaran dengan tujuan agar siswa secara aktif mengembangkan potensi dirinya untuk memiliki kekuatan spiritual keagamaan, pengendalian diri, kepribadian, kecerdasan, akhlak mulia, serta keterampilan yang diperlukan dirinya dan masyarakat, dalam berbangsa dan bernegara.

Berhubungan dengan kehidupan sosial dalam dunia pendidikan di pelajari pada mata pelajaran Ilmu Pengetahuan Sosial. Mata Pelajaran IPS merupakan mata pelajaran mata pelajaran yang mempelajari kehidupan sosial yang kajiannya mengintegrasikan bidang-bidang ilmu sosial dan humaniora adalah bidang studi yang

\footnotetext{
${ }^{1}$ Jejen Musfah, Manajemen Pendidikan, (Jakarta: Kencana, 2017), Cet.2, h.9
} 
mempelajari, menelah, menganalisis, gejala dan masalah sosial dimasyarakat dengan meninjau dari berbagai aspek kehidupan atau satu perpaduan. Menurut pasal 37 UU RI No.20 Tahun 2003 dinyatakan bahwa, mata pelajaran IPS merupakan salah satu bagian dari kurikulum pendidikan dasar dan menengah. Tujuan utama pendidikan IPS di SD mengembangkan potensi peserta didik agar peka terhadap masalah sosial yang terjadi dimasyarakat, memiliki sikap mental positif terhadap perbaikan segala ketimpangan yang terjadi, terampil mengatasi setiap masalah yang terjadi sehari-hari baik yang menimpa dirinya sendiri maupun masyarakat. ${ }^{2}$

Hasil belajar adalah kemampuan-kemampuan yang dimiliki siswa sebagai akibat perbuatan belajar dan dapat diamati melalui penampilan siswa. Hasil belajar atau pembelajaran dapat juga dipakai sebagai pengaruh yang memberikan suatu ukuran nilai dari metode (strategi) alternative dalam kondisi yang berbeda. Ia juga mengatakan secara spesifik bahwa hasil belajar adalah suatu kinerja yang diindikasikan sebagai suatu kapabilitas (kemampuan) yang telah diperoleh. Hasil belajar selalu dinyatakan dalam bentuk tujuan (khusus) perilaku (unjuk rasa). ${ }^{3}$

Peta adalah penggambaran seacar grafis atau bentuk skala (perbandingan) pada suatu konsep tertentu. Dalam hal ini peta merupakan alat untuk meyampaikan atau menginformasikan mengenai suatu ilmu. ${ }^{4}$ Konsep merupakan struktur mental yang diperoleh dari pengamatan dan pengalaman. Konsep adalah cara pendekatan yang mengarahkan peserta didik menguasai konsep secara benar dengan tujuan agar tidak terjadi kesalahan konsep. ${ }^{5}$ Metode Peta Konsep dalam pembelajaran merupakan cara mencatat yang efektif, efesien, kreatif, menarik, mudah dan berdaya guna karena

\footnotetext{
${ }^{2}$ Yulia Siska, Konsep Dasar IPS Untuk SD/MI, (Yogyakarta: Garudawaca, 2016), Cet.1, h.7

${ }^{3}$ Jamil Suprihatiningrum, Strategi Pembelajaran, (Jogjakarta: Ar-Ruzz Media, 2016), Cet.3, h.37

${ }^{4}$ Rolly Maulana Awangga, Pengantar Sistem Informasi Geografis, (Bandung: Kreatif Industri Nusantara, 2019), Cet.1, h. 21

${ }^{5}$ Taufiqur Rahman, Aplikasi Model-model Pembelajaran dalam PTK, (Jawa Tengah: Pilar Nusantara, 2018), Cet.1, h.31.
} 
dilakukan dengan cara memetakan konsep-konsep dalam materi pembelajaran. ${ }^{6}$

Peta konsep memegang peranan penting dalam belajar bermakna. Oleh karena itu siswa hendaknya pandai menyusun peta konsep untuk meyakinkan bahwa siswa telah belajar bermakna. Langkah-langkah berikut ini dapat diikuti untuk menciptakan suatu peta konsep: Langkah 1 Mengidentifikasi ide pokok atau prinsip yang melingkupi sejumlah konsep. Langkah 2 Mengidentifikasi ide-ide atau konsep-konsep sekunder yang menunjang ide utama. Langkah 3 Menempatkan ide utama di tengah atau di puncak peta tersebut. Langkah 4 Mengelompokkan ide-ide sekunder di sekeliling ide utama yang secara visual menunjukan hubungan ide-ide tersebut dengan ide utama. Sehingga dapat dikemukakan langkah-langkah menyusun peta konsep sebagai berikut: ${ }^{7}$

1) Menentukan topik atau materi dan memilih bahan bacaan yang sesuai dengan topik pembahasan.

2) Menentukan konsep-konsep yang relevan

3) Mengelompokkan (mengurutkan) konsep-konsep dari yang paling inklusif ke yang paling tidak inklusif.

4) Menyusun konsep-konsep tersebut dalam suatu bagan, konsepkonsep yang paling inklusif diletakkan di bagian atas atau di pusat bagan tersebut.

Ilmu pengetahuan sosial (IPS) merupakan integrasi dari berbagai cabang ilmu-ilmu sosial dan humaniora. Ilmu pengetahuan sosial dijadikan sebagai program pendidikan atau bidang studi dalam kurikulum sekolah yang mempelajari kehidupan manusia dalam masyrakat serta hubungan atau interaksi antara manusia dengan lingkungannya. Isi atau materi IPS diambil dan dipilih bagian-bagian pengetahuan/konsep dari ilmu-ilmu sosial disesuaikan tingkat pertumbuhan dan usia siswa. ${ }^{8}$

\footnotetext{
${ }^{6}$ Doni Swadarma, Penerapan Mind Mapping dalam Kurikulum Pembelajaran, (Jakarta: Elex Media Komputindo, 2013), Cet.1, h.3.

${ }^{7}$ M.Taufiq Rahman, Peta Konsep, (Bandung: Sosiologi FISIP,2016), h.8.

${ }^{8}$ Ibid, h.7
} 
Penelitian yang relevan, yaitu antara lain:

1. Skripsi Nova Deliani, Upaya Meningkatkan Aktivitas dan Hasil Belajar Siswa dengan Strategi Belajar Peta Konsep Pada Pembelajaran PKN Kelas V SDN 3 Mengandung sari Lampung Timur Tahun Ajaran 2017/2018

Pada penelitian ini terjadi peningkatan pada aktivitas belajar PKN dan peningkatan hasil belajar disetiap siklusnya. Yakni hasil penelitian di prasiklus hanya mencapai 33\%, siklus I meningkat mencapai $68,3 \%$ dan disiklus terakhir meningkat mencapai 79,91\%. Jadi dari siklus I ke siklus II aktivitas belajar siswa meningkat sebanyak $11,61 \%$. Kemudian hasil belajar siswa pada siklus I sebesar 71,43\% dan pada siklus II sebesar 85,71\%. Jadi dari siklus I ke siklus II hasil belajar siswa meningkat sebanyak $14,28 \%$. Persamaan dalam penelitian ini yaitu dengan menggunakan strategi pembelajaran yang sama yaitu melalui peta konsep, namun perbedaan dalam penelitian ini yaitu jika dalam penelitian ini meningkatkan hasil belajara pada mata pelajaran PKn, namun dalam penelitian peneliti bertujuan untuk meningkatkan hasil pelajaran pada mata pelajaran IPS.

2. Skripsi, Idawati, Upaya Peningkatan Hasil Belajar IPA Melalui Metode Peta Konsep Dengan Menggunakan Media Gambar Pokok Bahasan Sistem Pencernaan Manusia Siswa Kelas V SD N 2 Sorogaten Klaten Tahun Ajaran 2018/2019.

Berdasarkan hasil penelitian dapat disimpulkan bahwa, ada peningkatan hasil belajar IPA tentang sistem pencernaan manusia setelah dilaksanakan tindakan kelas melalui metode peta konsep dengan mengguanakan media gambar. Pada siklus 1 ada peningkatan dari nilai rata-rata 58,58 (kondisi awal) menjadi 67,65 dan dari pencapaian Kriteria Ketuntasan Minimal (KKM) dari $29,42 \%$ menjadi $70,58 \%$. Siklus II terjadi peningkatan dari nilai rata-rata 67,65 menjadi 84,29 dan dari pencapaian Kriteria Ketuntasan Minimal (KKM) dari 70,58\% menjadi 94,11\%.

Persamaan dalam penelitian ini yaitu dengan menggunakan strategi pembelajaran yang sama yaitu melalui peta konsep 
namun dengan tambahan media. Akan tetapi perbedaan dalam penelitian ini yaitu jika dalam penelitian ini meningkatkan hasil belajar pada mata pelajaran IPA, namun dalam penelitian peneliti bertujuan untuk meningkatkan hasil pelajaran pada mata pelajaran IPS.

3. Jurnal Wayan Darmayoga, Pengaruh Implementasi Metode Mind Mapping Terhadap Hasil Belajar IPS Ditinjau Dari Minat Siswa Kelas IV SD Sathya Sai Denpasar Tahun Ajaran 2018/2019.

Hasil penelitian menunjukkan bahwa dengan menggunakan metode Mind Mapping dapat meningkatkan hasil belajar IPS siswa di kelas IV SD Sathya Sai Denpasar. Dari hasil belajar siswa yang dilakukan pada penilaian pada setiap siklusnya mengalami peningkatan rata-rata nilai siswa. Hasil pada siklus I diperoleh nilai dengan rata-rata $67,63 \%$ dan terjadi peningkatan hasil belajar siswa pada siklus II nilai rata-rata mencapai $86,65 \%$.

Persamaan dalam penelitian ini yaitu sama-sama meningkatkan hasil belajar IPS. Akan tetapi perbedaan dalam penelitian ini yaitu jika dalam jurnal ini menggunakan Metode Mind Mapping, namun dalam penelitian peneliti menggunakan metode Peta Konsep.

\section{Metode Penelitian}

Jenis penelitian ini adalah Penelitian Tindakan Kelas (PTK). Penelitian Tindakan Kelas (PTK) adalah penelitian yang dilakukan secara sistematis reflektif terhadap berbagai tindakan yang dilakukan oleh guru sekaligus sebagai peneliti, sejak disusunnya perencanaan sampai penilain terhadap tindakan nyata di dalam kelas berupa kegiatan belajar mengajar untuk memperbaiki kondisi pembelajaran yang dilakukan. ${ }^{9}$

\section{Setting Penelitian dan Subjek Penelitian}

Penelitian ini dilaksanakan di Sekolah Dasar Negeri 65/II Sungai Bangsat Bungo. Subjek penelitian ini adalah siswa kelas III yang

\footnotetext{
${ }^{9}$ Benidiktus Tanujaya \& Jeinne Mumu, PTK: Tindakan Dalam PTK (Yogyakarta: media akademi 2016), h.4.
} 
berjumlah 24 orang, dengan jumlah siswa laki-laki 12 orang, dan siswa perempuan 12 orang.

Prosedur penelitian tindakan kelas yang peneliti jadikan acuan yaitu menurut model Kemmis dan Taggart yang memiliki beberapa komponen-komponen pokok penelitian tindakan setiap siklusnya, yaitu: 1) perencanaan (planning), 2) tindakan (acting) dan pengamatan (observing), 3) refleksi (reflecting). Kegiatan tersebut saling bertautan sehingga membentuk suatu siklus. Jumlah siklus dalam penelitian tindakan menurut model Kemmis dan Taggart, tergantung dari keberhasilan tindakan dalam menyelesaikan suatu permasalahan. Semakin banyak permasalahan yang belum diselesaikan melalui tindakan yang diambil, maka semakin banyak pula siklus yang perlu dilakukan.

Adapun model dan penjelasan untuk masing-masing tahap adalah sebagaimana gambar berikut ini.

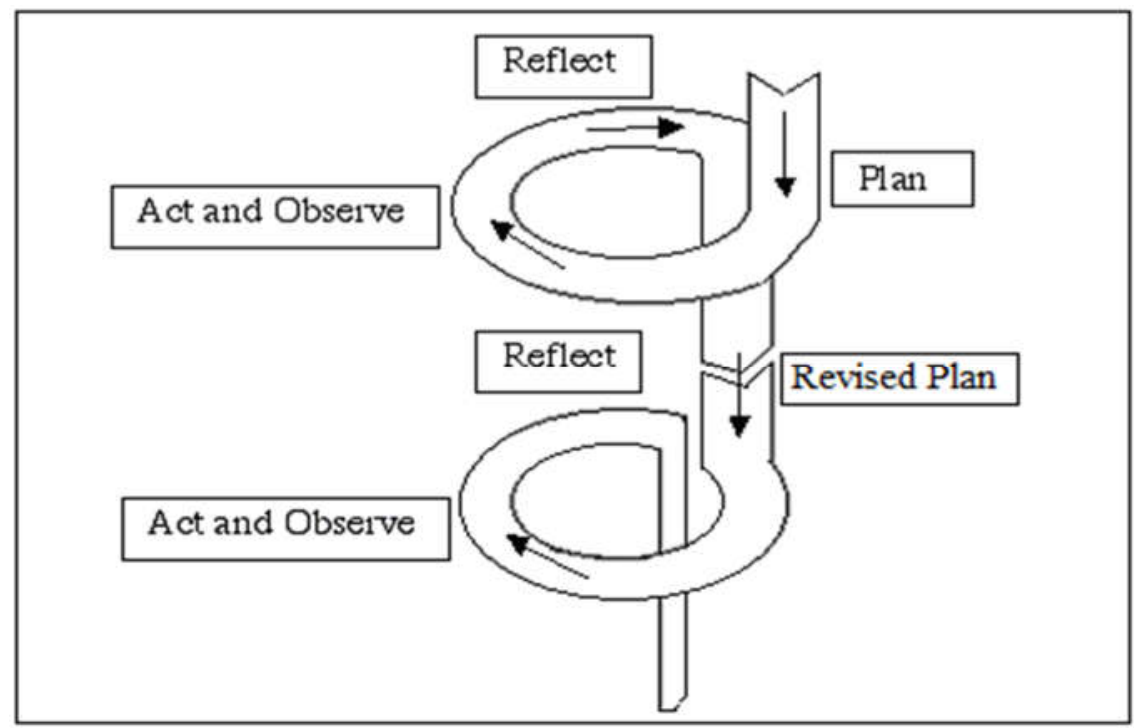

Gambar 3.1. Prosedur penelitian model Kemmis dan Taggart ${ }^{10}$

${ }^{10}$ Benidiktus Tanujaya dan Jeinne Mumu, PTK, (Bandung :Media Guru ), h.22 
Tahapan prosedur penelitian dapat diuraikan sebagai berikut:

\section{Siklus I}

a) Perencanaan

Pada tahap perencanaan hal-hal yang dipersiapkan diantaranya:

1) Menyiapkan RPP mata pelajaran Ilmu Pengetahuan Sosial.

2) Mempersiapkan media/sarana dan prasarana pembelajaran.

3) Mempersiapkan pedoman observasi.

4) Merancang soal tes hasil belajar.

5) Tindakan dan Observasi

Tindakan merupakan aktifitas yang dilakukan guru untuk mengatasi permasalahan yang ada. Tindakan merupakan jawaban bagaimana mengatasi permasalahan yang ada. Tindakan yang dapat dilakukan guru antara lain menggunakan Metode Peta Konsep dalam pembelajaran.

b) Pada saat peneliti melakukan tindakan, guru atau wali kelas bertindak sebagai observer melakukan pengamatan atau observasi selama proses pembelajaran IPS dilakukan dengan menggunakan beberapa alat bantu yang sudah dipersiapkan sebelumnya berupa pedoman observasi. Pedoman observasi juga digunakan untuk mengamati kesesuaian antara pelaksanaan tindakan dengan rencana pelaksanaan yang telah disusun. Pada tahap ini yang dilakukan oleh observer adalah mengamati aktifitas guru dalam mengajar, aktifitas atau perilaku siswa dalam mengikuti pembelajaran.

c) Refleksi

Refleksi adalah kegiatan mengulas secara kritis tentang perubahan yang terjadi di kelas. Setelah mengkaji proses pembelajaran peneliti juga mencari kekurangan dan membuat daftar permasalahan yang muncul dalam pelaksanaan siklus. Jadi Refleksi merupakan kegiatan untuk mengemukakan kembali apa yang sudah terjadi dan apa yang sudah dilakukan

Hasil dari refleksi ini akan digunakan untuk menetapkan langkahlangkah lebih lanjut dalam upaya mencapai tujuan penelitian tindakan kelas yang ditetapkan. Dengan perkataan lain refleksi merupakan pengkajian terhadap keberhasilan dan kegagalan dalam 
mencapai tujuan sementara, dan untuk menentukan tindak lanjut dalam rangka mencapai tujuan akhir. ${ }^{11}$

\section{Siklus II}

Siklus II dilakukan apabila harapan yang diinginkan peneliti belum tercapai, sehingga pada siklus II dilakukan perencanaan ulang dengan tahapan yang sama. Artinya Jikalau penelitian belum mencapai harapan peneliti, maka penelitian dilakukan ke siklus berikutnya. Dan apabila harapan sudah tercapai maka siklus penelitian dapat dihentikan. Prosedur pada di siklus II sama dengan prosedur pada siklus I, hanya saja pada tahap siklus II sudah dilakukan perbaikan melalui evaluasi/refleksi yang telah dilaksanakan pada tahap akhir siklus I.

Dalam mengetahui persentase ketuntasan hasil belajar siswa, menggunakan rumus sebagai berikut:

\section{Jumlah siswa yang tuntas belajar}

Presentase ketuntasan belajar $=$

Jumlah seluruh siswa

Untuk menganalis lembar observasi aktivitas siswa, peneliti memberi skor berupa skala penilaian yang dilihat dari kriteria yang telah ditetapkan oleh peneliti. Karena bertujuan untuk meningkatkan hasil belajar siswa, setiap kategori terdapat skala pengamatan yang diamati setiap perolehan hasil tes siswa berupa angka-angka, maka kategori penilaiannya sebagai berikut: ${ }^{12}$

Tabel 3.4 Skala Penilaian Siswa

\begin{tabular}{|l|c|}
\hline \multicolumn{1}{|c|}{ Kategori } & Skala Nilai \\
\hline Sangat baik & $80-100$ \\
\hline
\end{tabular}

${ }^{11}$ Benediktus Tanujaya dan Jeinne Mumu, Penelitian Tindakan Kelas, (Jakarta: Media Guru) h. 52.

${ }^{12}$ Benidiktus Tanujaya \& Jeinne Mumu, PTK: Tindakan Dalam PTK, h.80. 


\begin{tabular}{|l|l|}
\hline Baik & $60-79$ \\
\hline Cukup & $30-59$ \\
\hline Kurang & $0-29$ \\
\hline
\end{tabular}

\section{Hasil Penelitian}

\section{Deskripsi Kondisi Awal (Pra Siklus)}

Tahap pra siklus penelitian yang dilakukan peneliti bertujuan untuk mengetahui kondisi awal yang terjadi di lokasi penelitian. Penelitian ini dilaksanakan di Sekolah Dasar Negeri 65/II Sungai Bangsat Bungo. Subjek yang peneliti jadikan penelitian yaitu kelas III, dengan jumlah keseluruhan anak sebanyak 24 orang anak, yang terdiri dari 12 orang anak laki-laki dan 12 orang anak perempuan. Dari hasil observasi yang dilakukan peneliti menunjukkan bahwa, kurang terlibatnya siswa dalam aktifitas pembelajaran, sehingga berdampak pada rendahnya hasil belajar siswa. Kurangnya kegiatan dan penggunan metode belajar yang di gunakan guru sehingga belum membangkitkan semangat siswa dalam belajar.

Tahap pra siklus penelitian ini dapat disimpulkan bahwa perlu adanya pembenahan dan perbaikan terhadap permasalahan kegiatan pembelajaran yang terjadi di kelas III. Jika tidak dilakukan pembenahan dan perbaikan pada kegiatan pembelajaran bagaimana siswa bisa meningkatkan hasil belajar dan kemampuan lainnya. Berikut ini tabel hasil observasi pada tahap prasiklus:

Tabel.4.1 Hasil Observasi Prasiklus

\begin{tabular}{|c|c|}
\hline Nilai tertinggi & 80 \\
\hline Nilai terendah & 30 \\
\hline Jumlah siswa tuntas & 8 \\
\hline Jumlah siswa tidak tuntas & 16 \\
\hline Persentase siswa tuntas & $33 \%$ \\
\hline Persentase siswa tidak tuntas & $67 \%$ \\
\hline
\end{tabular}

Berdasarkan tabel tahap prasiklus diatas, perolehan hasil belajar siswa rendah. Terlihat Nilai tertinggi yang diperoleh siswa sebesar 80 dengan jumlah ketuntasan siswa hanya sebanyak 8 orang siswa 
memperoleh persentase ketuntasan sebesar 33\% dari jumlah kesesluruhan siswa. Sedangkan nilai terendah diperoleh siswa sebesar 30. Dan jumlah siswa yang tidak tuntas sebanyak 16 orang siswa, memperoleh persentase siswa yang tidak tuntas sebesar 67\% dari jumlah kesesluruhan siswa. Salah satu yang bisa dijadikan solusi dalam permasalahan ini yaitu melalui metode peta konsep dalam proses kegiatan pembelajaran.

\section{Deskripsi Siklus I}

Pada tahap siklus I, Pelaksanaan kegiatan pembelajaran di Sekolah Dasar Negeri 65/II Sungai Bangsat Bungo, akan paparkan dimulai pada tahap perencanaan, tindakan, observasi dan refleksi dalam kegiatan pembelajaran.

Pelaksanaan tindakan siklus I dilaksanakan pada :

Hari : selasa, rabu

Tanggal : : 10, 11 November 2021

Materi : Lingkungan (Lingkungan Alam dan Lingkungan Buatan).

Berikut ini deskripsi kegiatan pembelajaran yang dilaksanakan pada penelitian tindakan siklus I.

\section{a) Perencanaan}

Hal-hal yang perlu di persiapkan pada tahap perencanaan meliputi sebagai berikut:

1) Menyusun RPP (Rencana Pelaksanaan Pembelajaran)

\section{1) Deskripsi Tindakan Siklus I}

Berdasarkan catatan lapangan pelaksanaan kegiatan pembelajaran siklus I adalah sebagai berikut:

Nama Sekolah

Kelas

Materi

Buatan)

Uraian Kegiatan
: SDN 65/II Sungai Bangsat Bungo

: III

: Lingkungan (Lingkungan Alam dan Lingkungan

1) Pembukaan

Kegiatan pembukaan, guru memberikan penyambutan dengan bercerita tentang Covid dan keadaan dunia saat ini. Lalu guru mengarahkan anak-anak semuanya untuk mencuci tangan dengan 
sabun atau menggunakan hand sanitizer sebelum masuk ke kelas. Setelah itu, siswa lalu di bimbing masuk ke dalam kelas. Siswa duduk dengan rapi dan membaca doa bersama-sama sebelum belajar, serta membaca surat surat pendek. Setelah itu guru mengecek kehadiran siswa dan menanyakan kabar siswa. Dan menceritakan betapa pentingnya menjaga kesehatan. Sehingga guru memberikan nasehat untuk selalu mengatur pola hidup yang sehat.

Guru melakukan apersepsi dengan bertanya "siapa siswa ibuk yang tau lingkungan terbagi atas berapa?” Siswa pun menjawab "lingkungan rumah, lingkungan sekolah dan lingkungan masyarakat". Guru memberikan semangat dan mengucapkan kalimat "luar biasa" bagi siswa yang menjawab pertanyaan. Lalu Guru mendorong siswa yang lainnya untuk bisa mengungkapkan dan menjawab pertanyaan yang dilontarkan guru. Setelah itu guru mengajak anak untuk melakukan tepuk semangat, agar suasana kelas menjadi rileks dan semangat.

Setelah anak-anak melakukan beberapa tepukan semangat, guru pun mengajak siswa bernyanyi yang berhubungan dengan lingkungan. Setelah itu siswa ditunut untuk selalu mensyukuri apapun yang kita peroleh kepada Allah. Kita bisa belajar dan menuntut ilmu itu karena izinNya, sehingga kita memperoleh pengetahuan yang menjadi bekal dalam menjalani kehidupan. Lalu Guru menuliskan hari, tanggal dan tahun, serta materi yang akan dipelajari dan menyampaikan tujuan pembelajaran.

2) Kegiatan Inti

Dalam kegiatan inti, guru mengatur keadaan kelas dan memastikan siswa siap mendengarkan penjelasan guru. Dan guru melontarkan beberapa pertanyaan-pertanyaan kepada siswa mengenai materi lingkungan. Lalu guru mengatakan kalimat luar biasa bagi siswa yang berani menjawab pertanyaan guru.

Setelah itu Guru menjelaskan pembelajaran lingkungan alam dan buatan menggunakan peta konsep. Siswa mendapatkan informasi tentang materi yang disampaikan yaitu berhubungan dengan lingkungan alam dan buatan. Siswa mendapatkan materi lingkungan alam dan buatan. Siswa mendapatkan kesempatan untuk bertanya 
tentang informasi pembelajaran lingkungan alam dan buatan. Siswa mendapatkan kesempatan untuk merespon informasi yang di sedang dibahas.

Selanjutnya Guru ialah membagi siswa menjadi beberapa kelompok. Bertujuan agar antar siswa saling bekerja sama, saling bertanggung jawab untuk menyelesaikan tugas dalam kegiatan bersama dengan memperoleh tujuan arah yang lebih baik. Dengan kelompok adanya sistem pembagian tugas, sehingga siswa memperoleh pengalaman yang menuntunnya untuk amanah memegang tanggung jawab.

Setiap kelompok mendapat kesempatan untuk mengembangkan peta konsep yang awalnya diperoleh dari guru. Peta konsep dibuat sesuai kreatifitas kelompok. Peserta didik yang aktif diberikan katakata pujian dan yang belum aktif diberikan dorongan untuk ikut adil dalam tugas kelompok.

Setelah pembuatan peta konsep yang di kerjakan tiap-tiap kelompok selesai, guru mengarahkan setiap kelompok siswa untuk menjelaskan ringkasan materi menggunakan peta konsep yang mereka buat. Dalam kegiatan ini guru membimbing siswa untuk mempresentasekan hasil pekerjaannya. Siswa yang aktif diberikan kata-kata pujian dan yang belum aktif diberikan dorongan untuk ikut adil dalam tugas kelompok.

Kegiatan tersebut dilakukan secara berganti-gantian. Guru membimbing siswa untuk mencoba dan mengikuti proses pembelajarannya, sesuai dengan langakah dan rencana kerja yang disusun peneliti. Setelah itu, guru mencatat dan mendokumentasikan akifitas siswa dalam kegiatan pembelajarannya.

3) Kegiatan Penutup

Guru membimbing siswa untuk merangkum pembelajaran. Setelah itu, siswa dibagikan soal berupa tes evaluasi belajar siswa. Siswa mengerjakan soal tersebut. Setelah selesai, guru mengarahkan semua siswa merapikan alat-alat pembelajaran dan duduk dengan tertib. 
Guru dan siswa melakukan beberapa tepukan semangat agar suasana kelas kembali tenang. Bernyanyi bersama. Lalu Berdoa, dengan membaca doa setelah belajar. Dan menutup pelajaran.

\section{2) Deskripsi Observasi Siklus I}

Kegiatan observasi yang diamati ialah seluruh aktifitas siswa selama pembelajaran menerapkan metode peta konsep. Observasi dilaksanakan berdampingan dengan kegiatan pembelajaran.

Observasi dilaksanakan dalam kegiatan pembelajaran pada siswa kelas III menggunakan metode peta konsep yang berhubungan dengan pembahasan materi pelajaran. Selama kegiatan pembelajaran pada tahap siklus I, berjalan dengan lancar yang di mulai dari kegiatan awal sampai dengan kegiatan akhir. Dalam proses pembelajaran peneliti dalam pelaksanaannya sudah sesuai dengan yang direncanakan. Setelah anak dibimbing dan diberikannya penjelasan dan gambaran contoh bentuk kegiatan yang dilakukan siswa, dan siswa bisa mengikuti dan melakukan kegiatan pembelajaran dengan baik.

Kegiatan observasi metode peta konsep selama pengamatan, masih terdapat siswa yang malu-malu untuk melakukan kegiatannya, dalam pembuatan peta konsep kelompok ada yang acuh dalam pengerjaannya, bisa dikatakan dalam tahap membiasakan diri dalam mengikuti kegiatan yang dilakukannya. Pada tahap ini peran guru sangat dibutuhkan untuk mendorong siswa agar ingin mencoba melakukan kegiatan pembelajaran. Guru perlu memberikan apresiasi terhadap siswa tersebut.

Namun disamping itu, ada juga yang terlihat asik dengan kegiatan sendiri dan belum mengikuti petunjuk dari penjelasan guru. Sehingga pada tahap siklus I ini Peneliti dan guru lebih banyak memberikan bimbingan dan motivasi, tindakan tersebut dilakukan agar anak melakukan dan mengikuti kegiatan pembelajaran. Proses pembelajaran siklus I, guru mengupayakan untuk selalu memberikan semangat agar anak bisa mengembangkan peta konsep sesuai pengetahuan yang mereka terima. 
Kegiatan observasi dilakukan berbantuan dengan alat lembaran observasi, Peneliti mencatat kegiatan pembelajatan dengan bantuan lembar observasi. Dalam lembaran observasi, hal yang diamati tersebut harus sesuai dengan indikator pencapaian peneliti terhadap anak.. Dari hasil pengamatan yang dilakukan pada tahapan siklus I, disajikan dalam bentuk tabel. Berikut bentuk penilaian hasil siswa melalui tes pengetahuan siswa terhadap pembelajaran:

Tabel.4.2 Data Hasil Belajar Siklus I

\begin{tabular}{|l|l|c|c|}
\hline \multicolumn{1}{|c|}{ No } & \multicolumn{1}{|c|}{ Nama } & Hasil Belajar & ket \\
\hline 1. & & & \\
\hline 2. & Ananda Viona & 80 & Tuntas \\
\hline 3. & Daffa Hoir & 70 & Tuntas \\
\hline 4. & Eira Septia & 80 & Tuntas \\
\hline 5. & Falzil Hipni & 60 & Tuntas \\
\hline 6. & Gilang Prasetio & 50 & Tidak Tuntas \\
\hline 7. & Handayani & 60 & Tidak Tuntas \\
\hline 8. & Innasa Billa & 60 & Tidak Tuntas \\
\hline 9. & Indah Putri & 70 & Tuntas \\
\hline 10. & Jeni Anjani & 80 & Tuntas \\
\hline 11. & Keisya Nabila & 70 & Tuntas \\
\hline 12. & Nur Aini & 50 & Tidak Tuntas \\
\hline 13. & M. Ikhsan & 70 & Tuntas \\
\hline 14. & M. Fariq Walfaiz & 50 & Tidak Tuntas \\
\hline 15. & M. Ikhwanuddin & 60 & Tidak Tuntas \\
\hline 16. & M. Ropiqi Hanis & 80 & Tuntas \\
\hline 17. & Nidia Khoirunnisa & 90 & Tuntas \\
\hline 18. & Al Fahri & 70 & Tuntas \\
\hline 19. & Asmaul Zahra & 80 & Tuntas \\
\hline 20. & Nuri Fitria Azalia & 60 & Tidak Tuntas \\
\hline 21. & Reihan & 60 & Tidak Tuntas \\
\hline 22. & Rista & 80 & Tuntas \\
\hline & & & \\
\hline
\end{tabular}




\begin{tabular}{|l|l|c|c|}
\hline 23. & Yogi Antoni & 90 & Tuntas \\
\hline 24. & Zelia Zahtussipa & 50 & Tidak Tuntas \\
\hline & Jumlah & 1660 & $14 \mathrm{~T}$ \\
\hline & Rata-rata & 69 & $10 \mathrm{TT}$ \\
\hline
\end{tabular}

Tabel.4.3 Observasi Siklus I

\begin{tabular}{|c|c|}
\hline Nilai tertinggi & 90 \\
\hline Nilai terendah & 50 \\
\hline Jumlah siswa tuntas & 14 \\
\hline Jumlah siswa tidak tuntas & 10 \\
\hline Persentase siswa tuntas & $58 \%$ \\
\hline Persentase siswa tidak tuntas & $41 \%$ \\
\hline
\end{tabular}

Pada tahap siklus I, berdasarkan tabel data perolehan hasil belajar siswa diatas, siswa sudah mengalami perubahan hasil yang signifikan. Nilai tertinggi yang diperoleh siswa sebesar 90 dengan jumlah ketuntasan siswa sebanyak 14 orang siswa memperoleh persentase ketuntasan sebesar $58 \%$ dari jumlah kesesluruhan siswa. Sedangkan nilai terendah diperoleh siswa sebesar 50 dengan jumlah siswa yang tidak tuntas sebanyak 10 orang siswa, memperoleh persentase siswa yang tidak tuntas sebesar $41 \%$ dari jumlah kesesluruhan siswa.

Maka data yang diperoleh peneliti melalui metode peta konsep mengenai hasil belajar siswa mengalami peningkatan. Dari 33\% menjadi 58\% siswa yang tuntas. Akan tetapi perolehan hasil tersebut belum mencapai tujuan yang diharapkan peneliti yaitu belum mencapai indikator keberhasilan yang telah ditetapkan peneliti sebesar $80 \%$ siswa yang tuntas, sehingga perlu dilaksanakan siklus II.

b) Refleksi

Peneliti dan wali kelas III melakukan refleksi setelah melakukan tindakan dan pengamatan kegiatan pembelajaran. Tahap refleksi merupakan kegiatan untuk mengemukakan kembali apa yang sudah terjadi dan apa yang sudah dilakukan. Kegiatan refleksi merupakan 
kegiatan yang sangat penting untuk dilaksanakan perbaikan proses dalam kegiatan pembelajaran selanjutnya.

c) Hasil refleksi yang telah di temukan pada siklus I diharapkan dapat memberikan perubahan yang lebih baik terhadap hasil belajar siswa. Maka dari itu, perubahan ataupun penambahan kegiatan aktifitas siswa yang akan dilakukan nantinya di harapkan dapat meningkatkan hasil belajar siswa. Dengan mencari solusi yang tepat sesuai permasalahan yang ada, dan berpengaruh bagi hasil belajar siswa. Adapun beberapa permasalaha yang perlu di atasi dalam penelitian kali ini yaitu:

Tabel. 4.4 Hasil Refleksi siklus I

\begin{tabular}{|l|l|}
\hline No & Refleksi \\
\hline & $\begin{array}{l}\text { Kurangnya tingkat kefokusan siswa pada saat } \\
\text { dimulainya pelajaran }\end{array}$ \\
\hline $\begin{array}{l}\text { Siswa belum maksimal dalam memperhatikan } \\
\text { penjelasan dari guru }\end{array}$ \\
\hline
\end{tabular} \begin{tabular}{l} 
Kurangnya respon siswa selama proses pembelajaran \\
menyelesaikan tugas pembuatan peta konsep \\
\hline \\
$\begin{array}{l}\text { Masih terdapat siswa yang kurang aktif pada saat } \\
\text { pembelajaran }\end{array}$ \\
\hline $\begin{array}{l}\text { Perolehan rata-rata hasil belajar siswa pada siklus I } \\
\text { sebesar 69\% } \\
\text { Persentase jumlah siswa yang tuntas 63\% }\end{array}$ \\
\hline
\end{tabular}

Hasil refleksi diatas dapat peneliti jelaskan bahwasanya perlu adanya perbaikan terhadap kegiatan pembelajaran yang akan dilaksanakan. Tentunya dalam kendala ataupun permasalahan tersebut dijadikan bahan perbaikan pada tahap siklus penelitian selanjutnya. Maka dalam penelitian ini peneliti melakukan tahapan di 
siklus berikutnya. Yang perlu peneliti lakukan yaitu persiapan yang lebih matang untuk mengatasi permasalahan yang ditemukan. Dengan tujuan agar harapan peneliti dalam penelitian ini dapat tercapai yaitu hasil belajar siswa meningkat.

Salah satu yang harus diperbaiki kali ini yaitu guru harus mengkondisikan kesiapan siswa sebelum pelajaran dimulai. Yang perlu dilakukan guru adalah memberikan stimulus agar siswa memperhatikan materi pelajaran. Bentuk stimulus yang diberikan berupa pertanyaan yang menarik bagi siswa, dan timbul dari diri siswa rasa keingintahuannya dengan jawaban yang akan mereka ketahui.

Selanjutnya, guru memberikan motivasi agar siswa lebih aktif selama proses pembelajaran. Motivasi bisa diberikan lewat kata-kata hebat untuk anak, dan cerita yang menginspirasi. Dalam hal ini peran guru dibutuhkan pada kegiatan pembelajaran dalam tindakan penelitian. Salah satu yang bisa dilakukan guru lainnya ialah memberi reword bagi siswa yang bisa melakukan kegiatan pembelajaran dengan baik. Dengan begitu, menjadi tertantang anak yang kurang aktif sehingga bisa menimbulkan semangat baru dalam diri siswa untuk mengikuti pembelajaran.

\section{Deskripsi Siklus II}

Pelaksanaan penelitian siklus II, Pelaksanaan kegiatan pembelajaran di Sekolah Dasar Negeri 65/II Sungai Bangsat Bungo, akan paparkan dimulai pada tahap perencanaan, tindakan, observasi dan refleksi dalam kegiatan pembelajaran.

Pelaksanaan tindakan siklus II dilaksanakan pada :

Hari : senin, selasa

Tanggal : : 16, 17 November 2021

Materi : Lingkungan Alam dan Lingkungan Buatan.

Berikut ini deskripsi kegiatan pembelajaran yang dilaksanakan pada penelitian tindakan siklus II.

Perencanaan

Hal-hal yang perlu di persiapkan pada tahap perencanaan meliputi sebagai berikut:

1) Menyusun RPP (Rencana Pelaksanaan Pembelajaran) 
Perencanaan pembelajaran merupakan suatu proses kegiatan merumuskan tujuan-tujuan apa yang ingin dicapai oleh suatu kegiatan pembelajaran, cara apa yang digunakan untuk menilai pencapaian tujuan tersebut, materi atau bahan apa yang akan disampaikan, bagaimana cara menyampaikan bahan serta media atau alat apa yang diperlukan untuk mendukung pelaksanaan pembelajaran tersebut. Dalam tahap perencanaan ini RPP disusun agar dalam kegiatan pembelajaran menjadi terarah dan jelas, sehingga tujuan dalam pelaksanaannya dapat tercapai. RPP disusun dengan materi "Lingkungan".

2) Menyiapkan media pembelajaran.

Persiapan selanjutnya yang diperlukan guru ialah media ataupun alat, bahan bantuan dalam kegiatan pembelajaran yang sesuai dengan tujuan dan harapan peneliti. Dikarenakan peneliti memfokuskan penelitian meningkatkan hasil belajar melalui metode peta konsep maka media yang perlu disiapkan guru yaitu berupa media yang berhubungan dengan kegiatan aktifitas pembelajaran peta konsep. Media yang dipersiapkan kali ini yaitu karton, dan alat tulis lainnya.

3) Menyusun lembar observasi

Selanjutnya yang perlu dipersiapkan yaitu lembar observasi, yang akan digunakan dalam proses kegiatan pembelajaran. Lembar observasi dipersiapkan agar nantinya observer dapat melihat aktifitas guru dan siswa dalam pembelajaran serta menemukan beberapa kekurangan yang perlu ditindak lanjuti pada siklus berikutnya. Lembar observasi yang disiapkan ialah lembar observasi kegiatan guru dan siswa.

\section{a) Tindakan dan Observasi}

Tahapan selanjutnya dalam penelitian ini yaitu tindakan dan observasi. Pada tahap ini tindakan dan observasi dilakukan secara bersamaan. Pada saat peneliti melakukan tindakan atau kegiatan pembelajaran maka guru kelas langsung melakukan observasi berupa pengamatan pada aktivitas pembelajaran yang berlangsung. Secara bersamaan melakukan kegiatan obsevasi dengan menggunakan lembaran observasi. 


\section{1) Deskripsi Tindakan Siklus II}

Berdasarkan catatan lapangan pelaksanaan kegiatan pembelajaran siklus II adalah sebagai berikut:

Nama Sekolah

Kelas

Materi

Buatan)

Uraian Kegiatan
: SDN 65/II Sungai Bangsat Bungo

: III

: Lingkungan (Lingkungan Alam dan Lingkungan

1) Pembukaan

Pada kegiatan pembukaan, guru megucapkan salam dan mempersilahkan siswa duduk dengan rapi dan membaca doa bersamasama sebelum belajar, serta membaca surat surat pendek. Setelah itu guru mengecek kehadiran siswa dan menanyakan kabar siswa.

Dan menceritakan betapa pentingnya menjaga kesehatan. Guru memberikan cerita tentang Covid dan keadaan dunia saat ini. Lalu guru mengingatkan semua siswa untuk sering mencuci tangan dengan sabun atau menggunakan hand sanitizer sebelum masuk ke kelas.

Guru melakukan apersepsi dengan bertanya "siapa siswa ibuk yang masih ingat ada berapa jenis lingkungan di pembelajara yang kemarin?" Siswa pun menjawab "lingkungan alam, dan lingkungan buatan". Guru memberikan semangat dan mengucapkan kalimat "luar biasa” bagi siswa yang menjawab pertanyaan. Lalu Guru mendorong siswa yang lainnya untuk bisa mengungkapkan dan menjawab pertanyaan yang dilontarkan guru.

Setelah itu guru mengajak anak untuk melakukan tepuk semangat, agar suasana kelas menjadi rileks dan semangat dan mengajak siswa bernyanyi yang berhubungan dengan lingkungan. Setelah itu siswa diingatkan untuk selalu mensyukuri kepada Allah apapun yang kita peroleh saat ini. Karena kita masih bisa belajar dan menuntut ilmu itu karena izinNya, sehingga kita memperoleh pengetahuan yang menjadi bekal dalam menjalani kehidupan kedepan. Lalu Guru menuliskan hari, tanggal dan tahun, serta materi yang akan dipelajari dan menyampaikan tujuan pembelajaran. 
2) Kegiatan Inti

Dalam kegiatan inti, guru mengatur keadaan kelas dan memastikan siswa siap mendengarkan penjelasan guru. Dan guru menyampaikan bahwasanya akan ada reword bagi siapa yang aktif dalam kegiatan pembelajaran. Dan hasil pembuatan peta konsep yang menarik berhubungan dengan materi pelajaran lingkungan alam dan lingkungan buatan.

Setelah itu Guru menjelaskan pembelajaran lingkungan alam dan buatan menggunakan peta konsep. Siswa mendapatkan informasi tentang materi yang disampaikan yaitu berhubungan dengan lingkungan alam dan buatan. Siswa mendapatkan materi lingkungan alam dan buatan. Siswa mendapatkan kesempatan untuk bertanya tentang informasi pembelajaran lingkungan alam dan buatan. Siswa mendapatkan kesempatan untuk merespon informasi yang di sedang dibahas.

Selanjutnya Guru menugaskan kepada semua siswa untuk membuat peta konsep secara mandiri. Setiap siswa mendapat kesempatan untuk mengembangkan peta konsep yang awalnya diperoleh dari guru. Peta konsep dibuat sesuai kreatifitas siswa berhubungan dengan materi lingkungan alam dan lingkungan buatan. Penugasan secara mandiri dilakukan agar siswa paham langsung dengan materi tersebut, karena jika siswa sendiri yang membuat mereka akan mudah mengingat dan mengerti dengan konsep pembelajaranya. Peserta didik yang aktif diberikan kata-kata pujian dan yang belum aktif diberikan dorongan untuk ikut adil dalam tugas kelompok.

Setelah pembuatan peta konsep yang di kerjakan siswa selesai, guru mengarahkan siswa untuk menjelaskan ringkasan materi menggunakan peta konsep yang mereka buat. Dalam kegiatan ini guru membimbing siswa untuk mempresentasekan hasil pekerjaannya. Peran guru sangat dibutuhkan karena kegiatan ini memberikan tanggung jawab penuh kepada tiap-tiap siswa.

Kegiatan tersebut dilakukan secara berganti-gantian. Guru membimbing siswa untuk mencoba dan mengikuti proses pembelajarannya, sesuai dengan langakah dan rencana kerja yang 
disusun peneliti. Setelah itu, guru mencatat dan mendokumentasikan akifitas siswa dalam kegiatan pembelajarannya.

3) Kegiatan Penutup

Guru membimbing siswa untuk merangkum pembelajaran. Setelah itu, siswa dibagikan soal berupa tes evaluasi belajar siswa. Siswa mengerjakan soal tersebut. Setelah selesai, guru mengarahkan semua siswa merapikan alat-alat pembelajaran dan duduk dengan tertib.

Guru dan siswa melakukan beberapa tepukan semangat agar suasana kelas kembali tenang. Bernyanyi bersama. Lalu Berdoa, dengan membaca doa setelah belajar. Dan menutup pelajaran

\section{Deskripsi Observasi Siklus II}

Kegiatan observasi yang diamati ialah seluruh kegiatan anak selama aktivitas pembelajaran dalam penerapan metode peta konsep. Observasi dilaksanakan berdampingan dengan kegiatan pembelajaran. Observasi dilaksanakan dalam kegiatan pembelajaran pada kelas III menggunakan metode peta konsep yakni menambah kegiatan persentase, menyampaikan dan menjelaskan peta konsep yang dibuat siswa. Siswa diberi tanggung jawab penuh untuk menyelesaikan tuntutan tugas atau kegiatan dalam pembelajaran.

Selama kegiatan pembelajaran pada tahap siklus II, berjalan dengan lancar yang di mulai dari kegiatan awal sampai dengan kegiatan akhir. Dalam proses pembelajaran peneliti dalam pelaksanaan sudah sesuai dengan yang direncanakan. Setelah anak dibimbing dan diberikannya penjelasan dan gambaran contoh bentuk kegiatan yang dilakukan siswa, dan siswa bisa mengikuti dan melakukan kegiatan pembelajaran dengan baik.

Berdasarkan pengamatan selama kegiatan observasi metode peta konsep, hasil belajar siswa meningkat. Dalam proses pembelajaran yang berlangsung, guru mengupayakan untuk selalu memberikan semangat agar anak bisa mengikui kegiatan pembelajaran. Dan menambahkan kegiatan yang menantang mental anak. 
Kegiatan observasi dilakukan berbantuan dengan alat lembaran observasi. Peneliti mencatat kegiatan pembelajatan dengan bantuan lembar observasi. Dalam lembaran observasi, hal yang diamati tersebut harus sesuai dengan indikator pencapaian peneliti terhadap siswa. Dari hasil pengamatan yang dilakukan pada tahapan siklus II, data perolehan hasil belajar siswa. Berikut ini bentuk penilaian siswa melalui tes pengetahuan siswa terhadap pembelajaran yang sudah dilakukan, disajikan dalam bentuk tabel:

Tabel.4.5 Data Hasil Belajar Siklus II

\begin{tabular}{|c|c|c|c|}
\hline No & Nama & Hasil Belajar & ket \\
\hline 1. & Ananda Viona & 90 & Tuntas \\
\hline 2. & Angga Andara & 90 & Tuntas \\
\hline 3. & Daffa Hoir & 100 & Tuntas \\
\hline 4. & Eira Septia & 100 & Tuntas \\
\hline 5. & Falzil Hipni & 80 & Tuntas \\
\hline 6. & Gilang Prasetio & 80 & Tuntas \\
\hline 7. & Handayani & 90 & Tuntas \\
\hline 8. & Innasa Billa & 90 & Tuntas \\
\hline 9. & Indah Putri & 100 & Tuntas \\
\hline 10. & Jeni Anjani & 100 & Tuntas \\
\hline 11. & Keisya Nabila & 80 & Tuntas \\
\hline 12. & Nur Aini & 60 & Tidak Tuntas \\
\hline 13. & M. Ikhsan & 80 & Tuntas \\
\hline 14. & M. Fariq Walfaiz & 60 & Tidak Tuntas \\
\hline 15. & M. Ikhwanuddin & 80 & Tuntas \\
\hline 16. & M. Ropiqi Hanis & 90 & Tuntas \\
\hline 17. & Nidia Khoirunnisa & 100 & Tuntas \\
\hline 18. & Al Fahri & 90 & Tuntas \\
\hline 19. & Asmaul Zahra & 100 & Tuntas \\
\hline 20. & Nuri Fitria Azalia & 80 & Tuntas \\
\hline 21. & Reihan & 70 & Tuntas \\
\hline
\end{tabular}




\begin{tabular}{|l|l|c|c|}
\hline 22. & Rista & 100 & Tuntas \\
\hline 23. & Yogi Antoni & 100 & Tuntas \\
\hline 24. & Zelia Zahtussipa & 60 & Tidak Tuntas \\
\hline & Jumlah & 2070 & $21 \mathrm{~T}$ \\
\hline & Rata-rata & 87 & $3 \mathrm{TT}$ \\
\hline
\end{tabular}

Tabel.4.6 Observasi Siklus II

\begin{tabular}{|c|c|}
\hline Nilai tertinggi & 100 \\
\hline Nilai terendah & 60 \\
\hline Jumlah siswa tuntas & 21 \\
\hline Jumlah siswa tidak tuntas & 3 \\
\hline Persentase siswa tuntas & $88 \%$ \\
\hline Persentase siswa tidak tuntas & $12 \%$ \\
\hline
\end{tabular}

Berdasarkan tabel data perolehan hasil siswa pada siklus II diatas, dapat disimpulkan siswa sudah mengalami perubahan yang signifikan. Hasil belajar tertinggi yang diperoleh siswa sebesar 100 dengan jumlah ketuntasan siswa sebanyak 21 orang siswa memperoleh persentase ketuntasan sebesar 88\% dari jumlah kesesluruhan siswa. Sedangkan nilai terendah diperoleh siswa sebesar 60 dengan jumlah siswa yang tidak tuntas sebanyak 3 orang siswa, memperoleh persentase siswa yang tidak tuntas sebesar $12 \%$ dari jumlah kesesluruhan siswa. Hal ini disimpulkan ketuntasan hasil belajar siswa untuk pelaksanaan tindakan siklus II dalam pembelajaran IPS melalui metode peta konsep terlihat adanya peningkatan hasil belajar siswa sebelum dan sesudah diterapkan metode. Dari 58\% menjadi $88 \%$ siswa yang tuntas. Hal ini telah mencapai indikator keberhasilan yang telah ditetapkan sebesar $80 \%$ siswa tuntas, sehingga penelitian ini di hentikan.

\section{b) Refleksi}

Berdasarkan observasi tersebut, peneliti dan guru kelas III melakukan refleksi. Dalam penelitian tindakan kelas, Tahap refleksi merupakan kegiatan yang sangat penting untuk dilaksanakan 
perbaikan proses dalam kegiatan pembelajaran selanjutnya. Kegiatan refleksi ini dimaksudkan sebagai bahan masukan pada kegiatan yang akan dilaksanakan pada siklus selanjutnya.

Berdasarkan deskripsi dan hasil observasi pada siklus II, maka dalam pembelajaran ini ditemukan beberapa aspek bahwa:

Tabel. 4.7 Hasil Refleksi siklus II

\begin{tabular}{|l|l|}
\hline No & Refleksi \\
\hline & $\begin{array}{l}\text { Pada pembelajaran IPS siklus II ini guru sudah } \\
\text { menguasai kelas dengan sangat baik. }\end{array}$ \\
\hline & $\begin{array}{l}\text { Penyampaian materi ajar yang diberikan juga sudah } \\
\text { baik, sudah kesesuaian antara tujuan pembelajaran. }\end{array}$ \\
\hline & $\begin{array}{l}\text { Aktivitas belajar siswa juga sudah meningkat } \\
\text { baik, hal ini dapat dilihat dari cara guru memberikan } \\
\text { tugas bagi setiap siswa. Suasana pembelajaran juga } \\
\text { sudah berjalan lancar. }\end{array}$ \\
\hline $\begin{array}{l}\text { Hasil belajar ketuntasan siswa pada siklus II } \\
\text { menunjukkan persentase sebesar 88\%, hal ini terlihat } \\
\text { bahwa indikator yang ditetapkan sudah berhasil. }\end{array}$ \\
\hline
\end{tabular}

Tahap refleksi dilakukan untuk perbaikan tindakan yang sudah dijalankan. Akan tetapi siklus ke II yang dilakukan sudah dapat dikatakan berhasil sebab indikator-indikator yang diharapkan sudah mencapai kategori sangat baik. Dengan begitu siklus ini menjadi siklus terakhir pada penelitian penerapan metode peta konsep pada mata pelajaran IPS kelas III SDN 65/II Sungai Bangsat Bungo.

\section{Pembahasan}

Hasil belajar merupakan gabungan dari kata hasil dan belajar. Belajar adalah berusaha memperoleh kepandaian atau ilmu untuk merubah tingkah laku atau tanggapan yang disebabkan pengalaman. ${ }^{13}$

${ }^{13}$ Kamus Besar Bahasa Indonesia, (https://kbbi.web.id/hasil belajar, diakses pada maret 2018) 
Belajar memiliki arti “berusaha memperoleh kepandaian atau ilmu”. Definisi ini memilliki pengertian bahwa belajar adalah suatu proses yang ditandai adanya perubahan pada diri seseorang yang sedang belajar. Perubahan sebagai hasil dari proses belajar dapat ditunjukkan dalam berbagai bentuk seperti perubahan pengetahuan, pemahaman, sikap dan tingkah laku, keterampilan, kecakapan, kebiasaan dan perubahan-perubahan aspek-aspek lain yang ada pada individu yang belajar. ${ }^{14}$

Hasil belajar adalah kemampuan-kemampuan yang dimiliki siswa sebagai akibat perbuatan belajar dan dapat diamati melalui penampilan siswa. Hasil belajar atau pembelajaran dapat juga dipakai sebagai pengaruh yang memberikan suatu ukuran nilai dari metode alternative dalam kondisi yang berbeda. Ia juga mengatakan secara spesifik bahwa hasil belajar adalah suatu kinerja yang diindikasikan sebagai suatu kapabilitas (kemampuan) yang telah diperoleh. Hasil belajar selalu dinyatakan dalam bentuk tujuan (khusus) perilaku (unjuk rasa). ${ }^{15}$

Metode yang sesuai untuk merangsang aktifitas belajar siswa yakni dengan diterapkan salah satu metode yang menarik minat anak yaitu metode peta konsep. Peta konsep adalah bagan atau gambar yang berupa ilustrasi grafis yang menjelaskan tentang suatu hal yang berisi tentang hubungan antara beberapa konsep dengan konsep. Penggunaan peta konsep sangatlah penting dalam pembelajaran, sebab peta konsep membantu siswa membuat informasi yang abstrak menjadi konkret dan dapat memperkuat ingatan suatu konsep dalam sebuah materi pelajaran karna materi disajikan dengan ringkas dan menghubungkan konsep satu dengan yang lain dan diwakili dengan kata kunci sebagai bentuk pengingat dan penanda sebuah konsep pembelajaran.

Berdasarkan teori hasil belajar dan penerapan metode peta konsep diatas, maka untuk dapat meningkatkan hasil belajar siswa

\footnotetext{
${ }^{14}$ Nunuk \& Leo, Strategi Belajar Mengajar, (Yogyakarta: Penerbit Ombak, 2012), Cet.1, h.35

${ }^{15}$ Jamil Suprihatiningrum, Strategi Pembelajaran, (Jogjakarta: Ar-Ruzz Media, 2016), Cet.3, h.37
} 
yaitu dengan menerapkan metode peta konsep dalam kegiatan pembelajaran.

Hasil penelitian diperoleh dan dimulai pada tahap Prasiklus, Siklus I, dan Siklus II menunjukkan bahwa terjadi peningkatan terhadap hasil belajar kelas III SDN 65/II Sungai Bangsat Bungo dengan menggunakan metode peta konsep. Hal tersebut dapat dilihat dari persentase hasil perolehan siswa, pada prasiklus hanya sebesar $33 \%$ berada pada kategori kurang baik, lalu mengalami peningkatan pada Siklus I sebesar $25 \%$ menjadi $58 \%$ berada pada kategori cukup baik dan mengalami peningkatan kembali pada Siklus II nya sebesar 30\% menjadi $88 \%$ berada pada kategori sangat baik dari jumlah keseluruhan siswa kelas III di SDN 65/II Sungai Bangsat Bungo. Berikut pemaparan grafik peningkatan terhadap hasil belajar siswa, diawali pada tahap prasiklus, siklus I dan siklus II:

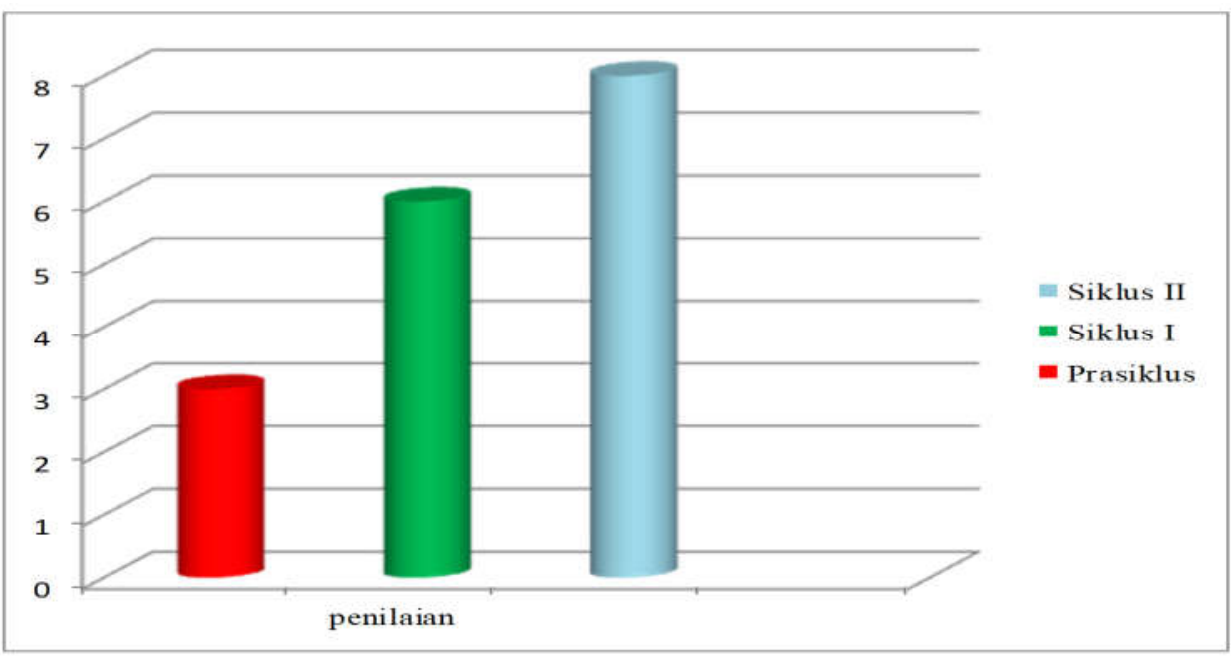

Diagram 4.1. Peningkatan Hasil Belajar Siswa

Hasil belajar siswa merupakan penilaian akhir dari proses dan pengenalan pembelajaran yang telah dilakukan berulang-ulang, karena hasil belajar turut serta dalam membentuk pribadi individu yang mencapai hasil yang lebih baik sehingga akan merubah cara berpikir serta menghasilkan perilaku kerja yang lebih baik. Jadi hasil 
belajar, merupakan hasil dari penguasaan ilmu pengetahuan yang diungkapkan dalam bentuk perubahan perilaku yang harus dicapai oleh siswa selama belajar di sekolah.

Melalui metode peta konsep dijadikan tindakan dalam penelitian ini karena jika menerapkan metode ini siswa dituntun untuk terlibat dalam menguasai bahan materi pelajaran. Dengan siswa terlibat langsung dalam proses pembelajaran, akan berkesan bagi diri siswa karena bertambahnya pengalamannya dalam menerima pengetahuan. Dengan metode peta konsep dapat meningkatkan hasil belajar siswa, baik melalui kegiatan secara individu maupun kelompok. Dengan begitu dengan diterapkannya metode peta konsep menghasilkan peningkatan yang signifikan terhadap hasil belajar siswa.

\section{Penutup}

Sekolah Dasar Negeri 65/II Sungai Bangsat Bungo menjadi lokasi penelitian tindakan kelas di lakukan pada kelas III. Berdasarkan penelitian yang diperoleh dari hasil observasi dapat disimpulkan bahwa hasil belajar siswa dapat meningkat melalui kegiatan metode peta konsep. Hal tersebut dapat dilihat dari peningkatan rata-rata persentase dari hasil penelitian yang dimulai pada tahap Prasiklus, Siklus I, dan Siklus II menunjukkan bahwa terjadi peningkatan terhadap hasil belajar siswa kelas III Sekolah Dasar Negeri 65/II Sungai Bangsat Bungo.

Penelitian tindakan kelas yang di lakukan pada siswa kelas III Sekolah Dasar Negeri 65/II Sungai Bangsat Bungo mengalami peningkatan terhadap hasil belajar siswa yang terjadi pada setiap siklus penelitiannya. Hal tersebut dapat dilihat dari persentase hasil perolehan siswa, pada prasiklus hanya sebesar $33 \%$ berada pada kategori kurang baik, lalu mengalami peningkatan pada Siklus I sebesar $25 \%$ menjadi $58 \%$ berada pada kategori cukup baik dan mengalami peningkatan lagi pada Siklus II nya sebesar 30\% menjadi $88 \%$ berada pada kategori sangat baik dari jumlah keseluruhan siswa kelas III di SDN 65/II Sungai Bangsat Bungo. 


\section{Daftar Pustaka}

Benidiktus Tanujaya \& Jeinne Mumu, PTK: Tindakan Dalam PTK, Yogyakarta: media akademi 2016.

Carli Wiseza Fitria, Konsep IPS Menuju IPS Zaman Now, Surabaya: Pustaka Media Guru, 2019.

Doni Swadarma, Penerapan Mind Mapping dalam Kurikulum Pembelajaran, Jakarta: Elex Media Komputindo, 2013.

Idawati, “Upaya Peningkatan Hasil Belajar IPA Melalui Metode Peta Konsep Dengan Menggunakan Media Gambar Pokok Bahasan Sistem Pencernaan Manusia Siswa Kelas V SD N 2 Sorogaten Klaten”.

Jamil Suprihatiningrum, Strategi Pembelajaran, Jogjakarta: Ar-Ruzz Media, 2016.

Jejen Musfah, Manajemen Pendidikan, Jakarta: Kencana, 2017.

Johni Dimyati, Metodologi Penelitian Pendidikan dan Aplikasinya pada Pendidikan Anak Usia Dini, Jakarta: Kencana, 2013.

M. Taufiq Rahman, Peta Konsep, Bandung: Sosiologi FISIP,2016.

Maulana Awangga Rolly, Pengantar Sistem Informasi Geografis, (Bandung: Kreatif Industri Nusantara, 2019.

Mona Novita, PTK Tidak Horor, Surabaya: CV. Pustaka Media Guru, 2018.

Muhammad Anwar, Filsafat Pendidikan, Jakarta: Kencana, 2015.

Nova Deliani, “Upaya Meningkatkan Aktivitas dan Hasil Belajar Siswa dengan Strategi Belajar Peta Konsep Pada Pembelajaran PKn Kelas V SDN 3 Mengandungsari Lampung Timur”.

Nunuk \& Leo, Strategi Belajar Mengajar, Yogyakarta: Penerbit Ombak, 2012. 
Rahman Taufiqur, Aplikasi Model-Model Pembelajaran dalam Penelitian Tindakan Kelas, Jawa Tengah: Pilar Nusantara, 2018.

Riadi Muchlisin, Peta Konsep (Pengertian, Manfaat, Jenis, dan Cara Pembuatan), 2020.

Sinar, Metode Active Learning, Yogyakarta: Budi Utama, 2018.

Wayan Darmayoga, "Pengaruh Implementasi Metode Mind Mapping Terhadap Hasil Belajar IPS Ditinjau Dari Minat Siswa Kelas IV SD Sathya Sai Denpasar.

Yulia Siska, Konsep Dasar IPS Untuk Sekolah Dasar/MI, Yogyakarta: Garudawaca, 2016.

Yulia Siska, Konsep Dasar IPS Untuk Sekolah Dasar/MI, Yogyakarta: Garudawaca, 2018.

Yusuf Muri, Asesmen dan Evaluasi dalam Pendidikan, Jakarta: Kencana, 2017. 